\title{
The development of a qualitative assay for male infertility from a study of enzymes in human semen
}

\author{
M. J. C. Crabbe* \\ Department of Obstetrics and Gynaecology, St. Mary's Hospital, \\ University of Manchester, Manchester MI3 OJH, U.K.
}

\begin{abstract}
Summary. Various enzymes in the semen of men were examined to see if any could be related to measures of fertility. Fumarase activity was highly correlated with sperm number and percentage motility. Diamine oxidase activity was higher in samples with sperm counts of $<20 \times 10^{6} / \mathrm{ml}$ and sperm motility of $<20 \%$. Monoamine oxidase, adenine deaminase and prostaglandin dehydrogenase were undetectable in significant amounts in all samples, while peroxidase and adenosine deaminase were not correlated with sperm count and motility. It is suggested that the simple spectrophotometric assays for fumarase and diamine oxidase could form the basis of a routine assessment of human semen samples for estimation of male infertility.
\end{abstract}

\section{Introduction}

Current methods of estimating semen quality are essentially qualitative, involving microscopic evaluation of sperm morphology and motility. When the sperm count is low, debris in the samples can give rise to erroneous and inconsistent results. The relationship between fertility, judged by the ability of the semen to promote conception, and determinations of sperm count and motility has been studied in the bull (Linford, Glover, Bishop \& Stewart, 1976) and man (Santomauro, Sciarra \& Varma, 1972). In both species it appears that although good motility is more important for conception than high sperm density, such techniques give an unreliable indication of fertility.

Biochemical estimates of enzyme activities and metabolites (e.g. cyclic nucleotide levels: Beck, Schonhofer, Rodermund, Dinnendahl \& Peters, 1976; polyamine levels: Fair, Clark \& Wehner, 1972; DNA content: Gledhill, 1966) have also failed to demonstrate any major correlations with infertility. Because of the qualitative nature of seminal fluid estimations and the lack of information about the enzymology of semen, the present study was undertaken to investigate a number of enzymes in the semen of oligospermic, vasectomized and normal men. The enzymes were chosen for their ease of assay, their direct quantitative method of measurement and for their possible importance in indicating the metabolic viability of ejaculated semen. It was hoped that if any correlations were found between the enzyme activities and routine semen investigation, they might form the basis of a rigorous and quantitative assay of semen quality for normal and infertile men.

\section{Materials and Methods}

\section{Semen collection and evaluation}

A total of 130 semen samples was obtained from oligospermic men attending infertility clinics at St. Mary's Hospital, Manchester, vasectomized patients and normal healthy volunteers. The volume, motility and sperm count of each sample were determined. The motility was estimated microscopically. Sperm counts were determined with a Coulter haemocytometer, and the mean of at least three readings was taken for each sample. The reproducibility of this method was better than $15 \%$ (1 standard deviation) for 10 separate dilutions, each counted 10 times. The samples were frozen within $10 \mathrm{~h}$ of emission and kept at $-15^{\circ} \mathrm{C}$ until further analysis. At emission, 45 further ejaculates

*Present address: Nuffield Laboratory of Ophthalmology, University of Oxford, Walton Street, Oxford, OX2 6AW, U.K. 
were centrifuged at $1000 \mathrm{~g}$ to separate the spermatozoa from the seminal plasma. The supernatant seminal plasma was decanted into cooled vials, and the pellet of cells was suspended in $1 \mathrm{ml}$ of $0.1 \mathrm{M}$-sodium/potassium phosphate buffer, $\mathrm{pH} 7 \cdot 0$, re-centrifuged, and the washings decanted to waste. After 3 such washings, the cells were suspended in $1 \mathrm{ml}$ of the buffer.

\section{Enzyme assays}

All enzyme activities were measured at $20^{\circ} \mathrm{C}$ on a Cary $118 \mathrm{C}$ recording spectrophotometer. All assays were carried out in 3-ml quartz cells in the sodium/potassium phosphate buffer of constant ionic strength $(I=\mathbf{0} \cdot 2)$ and of varied $\mathrm{pH}$ according to the assay used. The accuracy of the Gilson pipettes used was $\pm 5 \%$. Substantial deviations from linearity only occurred when there was an insignificant amount of enzyme present in the sample. In each assay $0.1 \mathrm{ml}$ semen, seminal plasma or sperm suspension was used, the optimal substrate concentrations being determined by initial experiments because of the non-linear kinetics reported for fumarase (Crabbe \& Bardsley, 1976), diamine oxidase (Scott, Childs, Crabbe, Tindall \& Bardsley, 1977), peroxidase (Childs \& Bardsley, 1975 ) and prostaglandin dehydrogenase (Bardsley \& Crabbe, 1976). The Cary spectrophotometer is able to measure repeatedly rates of change as low as 0.0002 absorbance units $\min ^{-1}$ : e.g. for peroxidase, 10 experiments gave an initial rate of $2.1 \times 10^{-3}$ absorbance units min $^{-1}$ (at $414 \mathrm{~nm}$ ) with a S.D. of $\pm 1.47 \times 10^{-4}$.

Fumarase (L-malate hydrolase, EC 4.2.1.2) was estimated by the method of Racker (1950) which utilizes the high absorbance of fumaric acid in the ultraviolet region of the spectrum relative to that of malic acid. The reaction can therefore be followed by the increase in absorbance in the ultraviolet region when malic acid is used as substrate. Test cuvettes contained $0 \cdot 1 \mathrm{ml}$ extract, $1 \mathrm{~mm}$-malic acid and $0.1 \mathrm{M}$-sodium/potassium phosphate buffer, $\mathrm{pH} 7 \cdot 0$, in a total volume of $3 \mathrm{ml}$, the reference cell containing only extract and buffer. The wavelength used was $250 \mathrm{~nm}\left(\varepsilon=1 \times 10^{3} \mathrm{M}^{-1} \mathrm{~cm}^{-1}\right.$ for fumaric acid) so that assays of fumarase and diamine oxidase could be run simultaneously in the multicell turret.

Diamine oxidase (histaminase, EC 1.4.3.6) was determined by the method of Bardsley, Crabbe, Shindler \& Ashford (1972) which utilizes a specific substrate to produce an aldehyde species when oxidation occurs with an absorbance peak at $250 \mathrm{~nm}$. The test cuvettes contained $0.33 \mathrm{~mm}-p$ dimethylaminomethylbenzylamine plus $0.1 \mathrm{ml}$ extract and phosphate buffer, $\mathrm{pH} 7.0$; the reference cells contained $0.33 \mathrm{~mm}$-p-bis(dimethylaminomethy1)benzene to correct for non-specific absorbance changes in the samples (Bardsley, Crabbe \& Scott, 1974). $p$-Dimethylaminomethylbenzaldehyde, the product of the enzyme reaction, has a molar extinction coefficient of $1.1 \times 10^{4} \mathrm{M}^{-1} \mathrm{~cm}^{-1}$ at $250 \mathrm{~nm}$.

Peroxidase was estimated by using $1 \mathrm{~mm}$-2,2'-azino-di(3-ethyl-benzthiazoline-6-sulphonic acid) as the chromogen at $414 \mathrm{~nm}$ and $\mathrm{pH} \mathrm{6.0.} \mathrm{For} \mathrm{the} \mathrm{radical} \mathrm{cation,} \varepsilon=3.6 \times 10^{4} \mathrm{M}^{-1} \mathrm{~cm}^{-1}$ at $414 \mathrm{~nm}$ (Childs \& Bardsley, 1975).

Monoamine oxidase was determined by the method of Tabor, Tabor \& Rosenthal (1954) with $0.33 \mathrm{~mm}$-benzylamine at $\mathrm{pH} 7.0$ and $250 \mathrm{~nm}$ as substrate. At $250 \mathrm{~nm}, \varepsilon=1.2 \times 10^{3} \mathrm{M}^{-1} \mathrm{~cm}^{-1}$ for benzaldehyde.

Adenine and adenosine deaminases were estimated by measurement of the decrease in absorbance at $270 \mathrm{~nm}$ caused by adenine $\left(\varepsilon=5.2 \times 10^{3} \mathrm{M}^{-1} \mathrm{~cm}^{-1}\right)$ or adenosine $\left(\varepsilon=8.33 \times 10^{3} \mathrm{M}^{-1} \mathrm{~cm}^{-1}\right)$ utilization (both at $0.033 \mathrm{~mm}$ final concentration) at $\mathrm{pH} 7.0$.

Prostaglandin dehydrogenase was determined by measurement of the increase in absorbance at $340 \mathrm{~nm}$ ( $\varepsilon$ for $\mathrm{NADH}+\mathrm{H}^{+}=6.33 \times 10^{3} \mathrm{M}^{-1} \mathrm{~cm}^{-1}$ ) and $\mathrm{pH} 7.0$ by using prostaglandin E-2 as substrate ( $0.33 \mathrm{~mm})$ and $\mathrm{NAD}^{+}$as cofactor ( $\left.0.08 \mathrm{~mm}\right)$.

Oxygen consumption by the enzyme extracts was determined with a Clark $\mathrm{O}_{2}$ electrode, calibrated with $\mathrm{O}_{2}$-saturated water $(0.291 \mathrm{~mm})$ and $\mathrm{O}_{2}$-free water at $20^{\circ} \mathrm{C}$ and $\mathrm{pH} 7 \cdot 0$. All chemicals were the highest grade commercially available; prostaglandin E-2 was given by the Pharmacy Department, St. Mary's Hospital, Manchester.

Statistical analyses were performed using two- and three-variable regression programmes on the Sumlock Compucorp 325 Statistician desk computer, with cassette tape memory (Armitage, 1971). 


\section{Results}

No significant monoamine oxidase, adenine deaminase or prostaglandin dehydrogenase activity was found in any of the semen samples tested (Table 1). Diamine oxidase, fumarase, peroxidase and adenosine deaminase exhibited marked variations in activity and these results were therefore analysed to discover whether this variation could be ascribed to semen quality, as judged by the usual methods of sperm count and motility. Peroxidase and adenosine deaminase activities did not correlate with either sperm number or percentage motility. Diamine oxidase activities were much higher at sperm counts of $20 \times 10^{6}$ and with samples of $<20 \%$ motility (Table 2). There was, however, a predominantly linear relationship between fumarase activity and both sperm number

Table 1. Enzyme activities (as units $\mathrm{ml}^{-1}\left(\times 10^{3}\right) \pm 1$ standard deviation when 1 unit of enzyme catalyses the utilization of $1 \mu \mathrm{mol}$ substrate/min at $20^{\circ} \mathrm{C}$ ) in human semen samples

\begin{tabular}{|c|c|c|c|c|c|}
\hline Enzyme & $\begin{array}{l}\text { No. of } \\
\text { samples }\end{array}$ & $\begin{array}{c}\text { After } \\
\text { vasectomy }\end{array}$ & $\begin{array}{l}\text { Whole } \\
\text { semen }\end{array}$ & $\begin{array}{l}\text { Seminal } \\
\text { plasma }\end{array}$ & $\begin{array}{l}\text { Sperm } \\
\text { cells }\end{array}$ \\
\hline $\begin{array}{l}\text { Diamine } \\
\text { oxidase }\end{array}$ & 175 & $0.8 \pm 1.7$ & $3 \cdot 0 \pm 7 \cdot 2$ & $9 \cdot 9 \pm 9 \cdot 5$ & $0.05 \pm 0.075$ \\
\hline Fumarase & 175 & $0.09 \pm 0.19$ & $1 \cdot 3 \pm 1 \cdot 6$ & $6.2 \pm 5.9$ & $0.01 \pm 0.04$ \\
\hline Peroxidase & 175 & $0.04 \pm 0.05$ & $2 \cdot 5 \pm 2.4$ & $1 \cdot 7 \pm 2 \cdot 1$ & $0.34 \pm 0.22$ \\
\hline $\begin{array}{l}\text { Monoamine } \\
\text { oxidase }\end{array}$ & 30 & N.D. & $0.02 \pm 0.03$ & N.D. & N.D. \\
\hline $\begin{array}{l}\text { Adenosine } \\
\text { deaminase }\end{array}$ & 175 & $0.2 \pm 0.2$ & $0.82 \pm 0.83$ & $0.7 \pm 0.7$ & $0.03 \pm 0.04$ \\
\hline $\begin{array}{l}\text { Adenine } \\
\text { deaminase }\end{array}$ & 30 & N.D. & N.D. & N.D. & N.D. \\
\hline $\begin{array}{l}\text { Prostaglandin } \\
\text { dehydrogenase }\end{array}$ & 30 & N.D. & $0.032 \pm 0.063$ & N.D. & N.D. \\
\hline $\begin{array}{l}\text { Oxygen utilization } \\
\quad\left(\mathrm{mm} \mathrm{min}^{-1} \times 10^{3}\right)\end{array}$ & 10 & N.D. & $2.6 \pm 1.9$ & $2 \cdot 5 \pm 1 \cdot 8$ & N.D. \\
\hline
\end{tabular}

N.D., not detectable.

Table 2. Diamine oxidase activity $\left(\Delta \mathrm{A}_{250} \mathrm{~min}^{-1} \mathrm{ml}^{-1} \times 10^{3}\right)$ in human semen (whole) as a function of sperm number and $\%$ motility

\begin{tabular}{lccccccccccc}
\hline Sperm no. $\mathrm{ml}^{-1} \times 10^{6}$ & 5 & 10 & 15 & 20 & 25 & 30 & 40 & 50 & 60 & 70 & 80 \\
Enzyme activity & 29 & 21 & 16 & 9.0 & 5.0 & 7.0 & 8.5 & 9.2 & 6.0 & 5.0 & 5.5 \\
& \pm 2.5 & \pm 2.5 & \pm 2.5 & \pm 2.0 & \pm 2.0 & \pm 3.0 & \pm 3.5 & \pm 3.0 & \pm 2.5 & \pm 2.2 & \pm 2.0 \\
\hline$\%$ Motility & 5 & 10 & 20 & 30 & 40 & 50 & 60 & 70 & 80 & 90 & \\
Enzyme activity & 50 & 48 & 44 & 15 & 9.0 & 8.8 & 8.2 & 6.5 & 5.5 & 5.0 & \\
& \pm 5.0 & \pm 4.5 & \pm 3.0 & \pm 2.5 & \pm 2.8 & \pm 2.5 & \pm 2.5 & \pm 2.5 & \pm 2.2 & \pm 2.2 & \\
\hline
\end{tabular}

Each value is mean \pm 1 S.D. for 130 samples. Sperm count and motility were estimated to the nearest decade or half-decade.

Table 3. Fumarase activity $\left(\Delta \mathrm{A}_{250} \min ^{-1} \times 10^{3}\right)$ in human semen (whole) as a function of sperm number and $\%$ motility

\begin{tabular}{|c|c|c|c|c|c|c|c|c|c|c|c|}
\hline $\begin{array}{l}\text { Sperm no. } \mathrm{ml}^{-1} \times 10^{6} \\
\text { Enzyme activity }\end{array}$ & $\begin{array}{c}5 \\
4.0 \\
\pm 1.2\end{array}$ & $\begin{array}{c}10 \\
5.0 \\
\pm 1.5\end{array}$ & $\begin{array}{r}15 \\
12 \\
\pm 2.0\end{array}$ & $\begin{array}{r}20 \\
14 \\
\pm 2.0\end{array}$ & $\begin{array}{r}25 \\
17 \\
\pm 3.0\end{array}$ & $\begin{array}{r}30 \\
18 \\
\pm 3.5\end{array}$ & $\begin{array}{r}40 \\
22 \\
\pm 20\end{array}$ & $\begin{array}{r}50 \\
25 \\
+3.5\end{array}$ & $\begin{array}{r}60 \\
27 \\
\pm 2.0\end{array}$ & $\begin{array}{r}70 \\
30 \\
+3.0\end{array}$ & $\begin{array}{r}80 \\
32 \\
+3.0\end{array}$ \\
\hline $\begin{array}{l}\% \text { Motility } \\
\text { Enzyme activity }\end{array}$ & $\begin{array}{c}5 \\
\text { N.D. }\end{array}$ & $\begin{array}{r}10 \\
4.0 \\
\pm 1.0\end{array}$ & $\begin{array}{r}20 \\
7.0 \\
\pm 2.0\end{array}$ & $\begin{array}{r}30 \\
8.5 \\
\pm 2.0\end{array}$ & $\begin{array}{r}40 \\
12 \\
\pm 1.0\end{array}$ & $\begin{array}{r}50 \\
13 \\
\pm 1.5\end{array}$ & $\begin{array}{r}60 \\
17 \\
\pm 2.5\end{array}$ & $\begin{array}{c}70 \\
19 \\
\pm 3.0\end{array}$ & $\begin{array}{c}80 \\
19.5 \\
\pm 2.5\end{array}$ & $\begin{array}{r}90 \\
24 \\
+20\end{array}$ & \\
\hline
\end{tabular}

Each value is the mean \pm 1 S.D. for 130 samples. Sperm count and motility were estimated to the nearest decade or half-decade. N.D., not detectable. 
and percentage motility (Table 3 ), with high correlation coefficients for both parameters $(0.96$, standard error of estimation $\mathbf{0 . 0 0 2 4}$ and 0.99 , standard error of estimation 0.008 , respectively). As expected, there was a significant correlation for whole semen between sperm count and motility $(r=0.43, P<0.001)$.

\section{Discussion}

Fumarase, one of the enzymes in the tricarboxylic acid cycle, showed a striking correlation of activity with both sperm number and percentage motility estimations, as would be expected if these determinations of semen potential were related to seminal metabolism. Fumarase activity was very much lower in the sperm cells than in the seminal plasma, indicating that the activity measurement in whole semen was due to the metabolic activity of the suspending fluid environment rather than of the spermatozoa themselves. The enzyme activity was unlikely to have leaked out during cell separation as activity in the washings was very low, but this does not preclude an equilibrium between fumarase in the sperm cells and the plasma in vivo if the cell membrane is permeable to the enzyme, or a leaking out of the enzyme during or after sperm cell maturation. The activities of fumarase and diamine oxidase were higher in seminal plasma than in whole semen; removal of the sperm cells by centrifugation might also remove inhibitors associated with the cells which control these enzyme activities.

High levels of diamine oxidase were found in the semen of infertile males with very low counts and motility of spermatozoa, and these are reflected in low spermidine levels, and lowered net spermidine synthase activity (Janne, Holtta, Haaranen \& Elfving, 1973).

The spectrophotometric assays for diamine oxidase and fumarase are reliable and accurate. They could be performed routinely on large numbers of semen samples, thereby providing information on which to judge the fertility of the donors.

I thank Dr M. Read for provision of seminal material; Mr G. Farrant for technical expertise in the qualitative estimations; Professor V. R. Tindall for laboratory facilities; Dr W. G. Bardsley for encouragement; Mr R. D. Waight for statistical advice; and the M.R.C. for the Cary spectrophotometer and Sumlock computer used in this study.

\section{References}

ARMtTaGe, P. (1971) Statistical Methods in Medical Research. Blackwell, Oxford.

Bardsley, W.G. \& CrabBe, M.J.C. (1976) Complex kinetics of prostaglandin dehydrogenase. Eur. $J$. Biochem. 68, 611-619.

Bardsley, W.G., Crabbe, M.J.C., Shindler, J.S. \& ASHFORD, J.S. (1972) Oxidation of $p$-dimethylaminomethylbenzylamine by pig kidney diamine oxidase. Biochem. J. 127, 875-879.

Bardsley, W.G., Crabbe, M.J.C. \& ScotT, I.V. (1974) Determination of diamine oxidase in biological fluids. Biochem. Med. 11, 138-146.

Beck, K.J., SCHONhofer, P.S., Rodermund, O.E., Dinnendaht, V. \& Peters, H.D. (1976) Lack of relationship between cyclic nucleotide levels and spermatozoal function. Fert. Steril. 27, 403-412.

ChILDs, R.E. \& Bardsley, W.G. (1975) Kinetics of the peroxidase reaction. Biochem. J. 145, 93-103.

Crabbe, M.J.C. \& Bardsley, W.G. (1976) NonMichaelian kinetics of fumarase. Biochem. J. 157, 333-337.

FAIR, W.R., Clark, R.B. \& WeHNer, N. (1972) $A$ correlation of seminal polyamine levels and semen analysis in the human. Fert. Steril. 23, 3842.

GLEDHILL, B.L. (1966) Studies on the DNA content of bull semen. Acta vet. scand. 7, 166-170.

JanNe, J., Holtta, E., HaAranen, P. \& Elfving, K. (1973) Polyamines and polyamine metabolising enzymes in human semen. Clin. chim. Acta 48, 393-401.

Linford, E., Glover, F.A., Bishop, C. \& Stewart, D.L. (1976) Relationship between semen evaluation methods and fertility in the bull. J. Reprod. Fert. 47, 283-291.

RACKer, E. (1950) Spectrophotometric assay for fumarase. Biochim. biophys. Acta 4, 211-214.

Santomauro, A.G., Sciarra, J.J. \& Varma, A. (1972) The role of the post-coital test in male infertility. Fert. Steril. 24, 772-775.

Scott, I.V., Childs, R.E., Crabbe, M.J.C., Tindall, V.R. \& BARDSLEY, W.G. (1977) Human placental amine oxidase and plasma diamine oxidase levels in pregnancy and cancer. In Proc. 7th Int. Congr. Clin. Enzymol., Venice (in press).

TABOR, C.W., TABOR, H. \& Rosenthal, S.M. (1954) Monoamine oxidase. J. biol. Chem. 208, 645-661. 